\section{$\underset{\substack{\text { hommes } \\ \text { \& migrations }}}{ }$}

\section{Hommes \& migrations}

Revue française de référence sur les dynamiques

migratoires

\section{9 | 2009}

L'Afrique en mouvement

\title{
La première étoile
}

Film français de Lucien Jean-Baptiste

\section{André Videau}

\section{(2) OpenEdition \\ 1 Journals}

Édition électronique

URL : http://journals.openedition.org/hommesmigrations/353

DOI : 10.4000/hommesmigrations.353

ISSN : 2262-3353

Éditeur

Musée national de l'histoire de l'immigration

\section{Édition imprimée}

Date de publication : 1 mai 2009

Pagination : 197

ISSN : 1142-852X

\section{Référence électronique}

André Videau, «La première étoile », Hommes \& migrations [En ligne], 1279 | 2009, mis en ligne le 29 mai 2013, consulté le 22 septembre 2020. URL : http://journals.openedition.org/hommesmigrations/ 353 ; DOI : https://doi.org/10.4000/hommesmigrations.353

Ce document a été généré automatiquement le 22 septembre 2020.

Tous droits réservés 


\title{
La première étoile
}

\author{
Film français de Lucien Jean-Baptiste
}

\section{André Videau}

1 La pratique du ski pendant les vacances d'hiver et de printemps a beau se démocratiser, on ne voit guère les familles antillaises, même aisées, se précipiter vers les stations de montagne à une période (fêtes de Noël, du jour de l'an ou de Pâques) où l'appel des îles natives se fait plus pressant: nostalgie du soleil et autres gourmandises, et tarifs préférentiels sur les compagnies aériennes.

2 Aussi, la surprise est totale lorsque le modeste Jean-Gabriel (le réalisateur Lucien JeanBaptiste qui met à contribution ses propres souvenirs) propose un séjour à la neige à sa famille au grand complet, sa femme Suzy (Anne Consigny), ses trois enfants et son inévitable maman, gardienne du foyer, surtout dans les moments pathétiques (la pétulante Firmine Richard qui se délecte de l'accent créole tout en marchant sur les trâces de Woopy Golberg).

3 La proposition est diversement appréciée. Jean-Gabriel a plutôt habitué les siens aux fins de mois difficiles, aux petits boulots à durée déterminée et sous-payés, à la fréquentation assidue et ruineuse des bars du PMU.

4 Il a beaucoup à se faire pardonner. Aussi, Il a tout prévu pour faire taire les récriminations et susciter l'enthousiasme. Le déplacement se fera avec la voiture empruntée à un copain (Edouard Moutoute, parfait chic type). L'appartement a été loué par correspondance. En voiture, tout le monde! Les monts blancs n'ont qu'à bien se tenir! Voilà une équipe haute en couleurs, capable d'aller à l'assaut des cimes et d'y décrocher les étoiles.

5 Comme il se doit, les propriétaires sont blancs et étonnés (Bernadette Laffont et Michel Jonaz tiennent le choc, et se tirent à peu près indemnes de la rencontre inopinée d'un couple de retraités franchouillards et d'une famille métisse débordante d'énergie). Cela nous vaut une série de quiproquos, aussi prévisibles qu'inoffensifs. Voici donc une version, en demi-teinte, des "bronzés font du ski". Gentille pochade anti-raciste, à déguster comme un sorbet sous les parasols. Dans les discussions à bâton rompu, les visages pâles ne font pas moins bonne figure que leurs frères de couleur. Le choc 
climatique et culturel n'aura pas lieu. Il aurait peut-être fallu répandre un peu plus de sel pour dégager la piste et l'intrigue de conventions seulement plaisantes. 